\title{
The Analysis of Dickens's Humanitarianism in a Tale of Two Cities
}

\author{
Qun $\mathrm{Li}^{1}$ \\ ${ }^{1}$ Department of foreign language teaching, Taishan University, Taian City, Shandong Province, China \\ Correspondence: Qun Li, Department of foreign language teaching, Taishan University, Taian City 271021, \\ Shandong Province, China. Tel: 13295382888. E-mail: liqunmiss@163.com
}

Received: December 26, 2013 Accepted: January 17, 2014 Online Published: February 26, 2014

doi:10.5539/ass.v10n6p155

URL: http://dx.doi.org/10.5539/ass.v10n6p155

\begin{abstract}
Charles Dickens, is a critical realist famous all over the world in the 19th century. His works are always full of thick soft heart and reflect deep ideal of Humanitarianism. He lives in the time which is famous for Victorian morality. Founded on his hard real life, he has produced a large amount of great works to expose the true sense of life. He advocates Humanitarianism and treats morality as a banner to guide people's fraternity. He intends to build a beautiful and peaceful world for people. A Tale of Two Cities is one of his representative works, which reflect his ideal of Humanitarianism.
\end{abstract}

Keywords: humanitarianism, a tale of two cities, limitation

Humanitarianism is an ethic of kindness, benevolence, and sympathy extended universally and impartially to all human beings. Humanitarianism has been an evolving concept historically but universality is a common element in its evolution. No distinction is to be made in the face of suffering or abuse on grounds of gender, sexual orientation, tribe, caste, age, religion, or nationality. Humanitarianism can also be described as the acceptance of every human being for plainly just being another human, ignoring and abolishing biased social views, prejudice, and racism in the process, if utilized individually as a practiced viewpoint, or mindset. It seriously concerns about human values. It is the idea of human's basic living conditions and pays attention to human well-being, emphasizes mutual aid between human beings. It relates with the importance of human values. At the same time, it has ideas of paying importance to god class and natural kinds or animals." Humanitarianism, as a trend of thought in the west, started from the Renaissance period. Humanitarianism came from the Latin word "Humanistas". Humanitarianism advocated people-oriented, which is positive to people's values and dignity and calls for liberation of personality. Humanists believe people have the right to pursue happiness and individual freedom. Humanity is the ideal starting point for them, the basis for their theory as well. Humanity is the ideal starting point for them, the basis for their theory as well.

Charles Dickens was a famous nineteenth-century English novelist. Victorian era, the time he lived in, was famous for morality. He promoted humanitarian through writing and criticized the corrupted life from a moral perspectives. Humanitarianism of Dickens's novels is built on the basis of human nature and his understanding of human nature is a common property of mankind. This is the starting point of his ideology of Humanitarianism. He fantasizes that the wicked people would have their conscience and turn over a new leaf to benefit the society. At his three literary creation points, he regarded Humanitarianism as the guiding principle of his works. He never stopped preaching about morality, and regarded his own works as a banner of ethical culture. He called on the rich and poor to overcome their own prejudices, to understand and love each other to build a better society. On the foundation of the impact of the ideological background and Dickens's hard experiences, he formed his particular Humanitarianism.

\section{The Formation of Dickens's Humanitarianism}

Dickens's Humanitarianism is a kind of capitalist Humanitarianism. Its particular nature is related to the ideological background of the times and Dickens's hard life experiences.

\subsection{The Ideological Background of the Times}

The time in which Dickens lived, was just as he described in volume I chapter 1 "The Period", "It was the best of times, it was the worst of times, it was the age of wisdom, it was the age of foolishness, it was the epochs of belief, it was the epoch of incredulity ..." 
Class contradictions of the British were very sharp in that period. With the Industrial Revolution continuing to penetrate all aspects of British society, contradiction between emerging class and the old became weaker. The fight between the working class and the bourgeoisie became the principal contradiction of British society in the 1830s. The bourgeoisie not only exploited wealth by expanding overseas, but also stepped up their brutal repression and exploitation of workers. Even after a parliamentary reform in 1832, the living conditions and wages of workers have not been greatly improved. On the contrary, their life became poorer. The worsening situation makes the working class in 1836 launched a vigorous "Charter Movement" (1838-1848). The movement has experienced three climaxes, while it didn't achieve its initial objectives. Nevertheless, the social issues it raised-anger and discontent expressed by the general public, had a tremendous intellectual impact on the United Kingdom. Dickens formed his particular kind of Humanitarianism under the influence of the time.

\subsection{Dickens's Hard Life Experiences}

Charles Dickens was born in a small staff family, in Portsmouth of England. He started work as an apprentice in a workshop since he was 12 . He once worked as practice hygiene in law firm, interviewer in a civil, journalist in a newspaper office. He rushed off his feet all day to live and experienced a lot of hardships and bulations. As the beginning of life, childhood experience gave birth to the sum of the psychological experience of the writers' initial life, including childhood emotions with the colors of various feelings, impressions, memories, knowledge, determination and many other kinds of factors. In Tong Qingbing's article "writer's childhood experiences and its impact on the creation", he commented that "almost every great writer regards his own childhood experiences as great valuable regretful gifts, as inexhaustible source of creativity".

Dickens's painful childhood experiences enveloped a layer of lingering shadow on his heart, but also made him erect a weighing of the "good" and "evil" moral balance in his heart. They laid a solid foundation for him to build his spirit of Humanitarianism. These experiences made him contact widely with British social life, understand the lower classes sufferings and became familiar with the various representatives' true features of the bourgeoisie. Therefore he formed his simple Humanitarianism thinking. He opposed every inhuman phenomenon, and tried to help unfortunate people in practice. "Real life has improved his humanitarian qualities, and has laid the foundation of life for literary creation."

\section{Dickens's View of Humanitarianism}

Dickens not only gave help in practice, but also aroused people's sense of responsibility and drew attention to the plight of people on bottom of society through his works. His thought of culture and moral roughly contains 3 points.

\subsection{Expecting the Rich to Find Their Conscience}

Dickens claimed to defend human dignity and hoped that the rich would find their conscience. That's the early point of moral and cultural ideas. Dickens's early works were influenced deeply by the Charter Movement's spirits-democracy, freedom and equality. He advocated all labor's right of work peace and happiness. He used novels to satirize the dark of educational institutions, the farce of the parliamentary elections, the ferocious nature of poor law, the hypocrisy of the religion liars and other social evils. He believed in the mercy of the rich and expected that the rich people would have conscience, and conscientiously improve the social abuses.

\subsection{Expecting to Improve the Society through Education}

With the deeper understanding of real life, Dickens began to be disappointed in the kind-hearted rich gradually. At that time, he recognized it was nearly impossible that the rich find their conscience by themselves. He wanted to transform assets and the society through the suffering of education and warmth probation. He expected the administrator would be nicer to the poor people so the poor and the rich would both live happier with each other.

\subsection{Teaching People to Abandon Evil to Good}

The last point is that he expressed his humanitarian ideas by teaching people to abandon evil to good. Although Dickens was increasingly disappointed in the bourgeoisie and even became pessimistic, he still kept shouting through his works in order to teach people to abandon evil to the good. In A Tale of Two Cities, Dickens preached forgiveness, love, altruism, self-sacrifice, and elimination of hatred, and then save the society. Thus, Darnay was the kind nobility who automatically gave up property. Manette was the symbol of forgiveness, not revenge against enemy civilians. Carlton was an altruistic young man who was for others at the expense of his own life.

To sum up, Dickens's literary works contain of 3 decades. His works were filled with the strong moral tone. He emphasized human equality, fraternity and he believed that human values depended on good or evil of people's 
hearts. He treated humanitarian as a responsibility, the literary works as a banner. He wanted people to love each other, to treat all living things with benevolence, righteousness and love. He hoped to eliminate all social ills and create a better life.

\section{Dickens's Humanitarianism in A Tale of Two Cites}

In the description of the novel of $A$ Tale of Two Cites and shaping of characters, Dickens interpreted the essence of Humanitarianism as humanity, forgiveness, self-sacrifice and kindness of people. He highly praised the miracle, greatness and strength. In the following part, Dickens's Humanitarianism will be analyzed from different perspectives through $A$ Tale of Two Cities.

\subsection{Doctor Manette's Forgiveness}

Manette, the core of the family, had a strong sense of justice. He was brave enough to reveal Evremonde brothers' crimes. Though trapped in Figure circle for 18 years, he still considered humanitarian as his belief. He hated the marquis brother immensely. So when he found that his daughter Lucy deeply loved Darnay who was a descendant of the Marquis, the pain he bore in his heart was so intense that it was unimaginable for ordinary people. The author did not describe his pain and contradictions. Instead, he made a lot of bedding. When Darnay told Manette sincerely that his love for Lucy was so unswervingly, he hesitated and was fearful for Darnay's love for her daughter. On the wedding of Lucy and Dannay, he was also very sad, but he conquered his feelings. Then the author had spent a lot of space describing how Manette was in schizophrenia again-neither recognized anyone, nor remember anything, just mechanical and woodenly repeated shoemaking .The author made this series of detailed micro-description of Manette to represent the doctor's pain and contradictions. But it can be seen that he desperately suppressed his personal grudges then his pain reached the farthest point and he fell in schizophrenia. So a great father leapt off and was shown before the readers. Manette finally got the better of him and accepted the enemy's offspring, which was indebted to his love for all. The author even described him as a saint living among mortals. He treated everyone in the same way no matter he was a friend or an enemy. He silently and suitably did operations on anyone who needed him, no matter who he is, a killer or a victim in the prison. Manette was a representative of the good and love the author characterized carefully. He was an example of Humanists. The writer intended to tell people that forgiveness and forbearance is assurance of happy and peaceful life.

\subsection{Darnay's Rebellion to His Class}

Darnay, as a rebel of nobles, was an ideal leading character in the writer's heart. He had so many merits: gentle manners, sincerity, seriousness and politeness. He fell in love with Lucy devotedly, but he did not impose his own feelings on her. He was willing to wait patiently until Lucy herself had the same affection, and then he opened his heart to her. He felt ashamed for his families' past crimes, and disliked his uncle Evremonde who was arbitrary and imperious. Refusing to inherit the hereditary peerage and territories, he abandoned enjoying the honorable and leisurely life. He came to England alone and worked as a professor of French self-reliantly. On the eve of the Revolution, he felt pity for people and let his steward reduce taxes. He let his steward Gabelle help the people as soon as possible-give them firewood in winter and agricultural products in summer. After the outbreak of the Revolution, Gabelle was involved and thrown into the prison. In order to maintain benevolence and Humanitarianism, Darnay took chance to come back to his country to save the poor prisoner. Unfortunately, he fell in trap and was sentenced to death. At that time, what he cared about was not himself but the safe of his wife and father-in-law. This is the image of ideal youth in Dickens's brain. In the author's view, Darnay's rebellion to his class, and his love for the people was honorable and full of Humanitarianism. So Darnay had a happy ending in the novel: when he was sent to the guillotine to be executed by the revolutionaries, Carton was willing to replace him and he was secretly sent back to London.

\subsection{Lucy's Kindness}

Lucy, a small bourgeois paternalism, was a tie who maintained the family. Similar to Madame Defarge, she had an unfortunate experience-her family was persecuted by Evremonde brothers. The difference was that she didn't revenge herself on the aristocracy like Madame Defarge. It was clear that she was a link of love that connected the two families who were once enemies. It indicted that love eliminated hatred.

Lucy was a nice girl who was very dutiful. Although she was separated from her father since she was very young, when she heard her father was still alive in the world, she went off in a faint because of pleasure. When she finally saw her father who was completely different due to torture in the prison, with a deep love, Lucy finally awakened her father who had died of heart. She took care of his father in everyday life in any possible way to make her father forget the past and restore the life, love, business, rest and well-being. 
Lucy was also a dutiful wife and loving mother. She made her family in a good order and even taught her daughter on time every day in the most difficult days of Paris. She loved her husband so much that when she knew that he was in danger, she left her peaceful and comfortable house in England for the bloody and terrible Paris. She did anything she could to save her husband, even went down on her knees before Madame Defarge and begged her to let off her husband. After Darnay was thrown into the prison unfortunately, she kept standing beside the wall for two hours every afternoon whether it was rainy or sunny in order that her husband could see her.

Lucy loved every person, including her families and all people around her. When she was requested to give evidence on the court for Darnay, she was filled with sympathy and solicitude, even at that time Darnay was just a stranger met by chance. When she had to say something that might testify against Darnay, she even burst into tears. Her kindness and benevolence can be seen from the way she treated a stranger. The author also strengthened her character from Lucy's attitude towards Carton. When Carton expressed his love for her, she was so sympathetic to him, and enthusiastically wanted to help him, and even shed tears of sincerity. This was Lucy, a lovely person who was concerned about the suffering of others when she was enjoying her sweet life. Her heart was full of benevolence to friends and strangers.

\subsection{Carton's Self-Sacrifice-The Highest Expression of the Humanitarian Ideal}

Carton, a young lawyer in England, was a curious man with complex characters. He had close relationship with Lucy's family. He felt disappointed at the setback of life. He detested the community but was unable to resist it. Then he gradually became indulgent, cynical, lazy, and degenerated. He knew his own shortcomings, but was unable to correct them, so he felt lonely and distant. Considering that his future was bleak and there was no space for him to live, after he fell in love with Lucy, he thought himself had been degenerated for a long time and unable to improve. In his view, it was impossible for him to give Lucy happiness. He deprived his right of loving Lucy by himself and withdrew from the love race. He finally fulfilled his promise-going on the guillotine instead of Intel for the happiness of Lucy's family. He shielded a tyrannical strength which was impossible to be held off for others with his body that was not robust. He saved the lives of four innocent people. That was the way he expressed his utmost love to Lucy. His love was not only beyond the worldly love, but also reached the sacred realm. Carton's self-sacrificing spirit was greatly praised by Dickens. That was the highest expression of the humanitarian ideal.

Dickens believed in Humanitarianism so much that he did many things to help the poor people and call on others to believe Humanitarianism and use it to solve the social problems. In the novel A Tale of Two Cities, he portrayed different types of characters who had various ending to inspire people to be kind and forgiving and he showed his Humanitarianism in this novel.

\section{The Limitations of Dickens's Humanitarianism}

Many characters, which were portrayed vividly, and complex stories completely showed Dickens's intention to display the sharp class contradictions between the feudal aristocracy and the working class. But Dickens only saw the contradiction between the working people and the feudal nobles, while he ignored "the British and French governments' exploitation of the people and made foreign wars year after year launch aggression, the calamities caused by continuous expansion of oversea colonies to the people". So that was why Dickens's Humanitarianism was not comprehensive and accurate. That's where his limitations lay.

\subsection{Dickens's Weakness in Characters}

Doctor Manette was an ideal figure the author greatly appreciated. He was kindhearted, naive, generous and honest. He was a well-learned and skillful doctor who sympathized with the poor people. As an upright man, he couldn't stand the Evremonde brothers' imperiousness and made up his mind to expose the nobles and marquis' unconscionable crimes to the court. He finished a complaint against the Marquis' crimes in blood when he was in prison. But in the end, after a long-term prison life, he gave up fighting and became numb. After his release, he did not fight in Paris but fled to London escorted by his daughter. Finally, after he learned that his daughter's lover was the descendant of his enemies who framed him, he forgave him.

Dickens arranged that Manette finally enjoyed his family's happiness, harmony and peace to support his victory of tolerance and benevolence. He believed that was the way in easing social conflicts. He believed that only tolerance and benevolence could ultimately ease the class conflict, and make the working people live in harmony with the aristocratic class. At the same time, only the moral education could the society is reformed. This was Dickens ideology compromise and revolutionary incompleteness. Dickens's limitations in his understanding reduced the novel's realism force. 


\subsection{Dickens's Fear of Revolution}

Madame Defarge was an example of hatred and revenge. She had animosity accumulated for decades in her heart. She just waited to revenge herself on enemies brutally. Dickens portrayed her as a bloodthirsty, indiscriminate killing of innocent, crazy and cold avenger.

In Madame Defarge's view, it was nothing to her, that an innocent man was to die for sins of his forefathers; she saw, not him, but them. It was nothing to her that his wife was to be a widow and his daughter an orphan; that was insufficient punishment, because they were her nature enemies and her prey, and as such had no right to live. To appeal to her, was made hopeless by her having no sense of pity, even for herself.

Madame Defarge did not always speak, but you would feel afraid when glancing at her. She always kept her knitting in her hands anytime and anywhere. It seemed that she wanted to knit all her hatred into her knitting without leaving any out. Madame Defarge called her knitting shroud. She wanted to knit everyone she hated deeply into her knitting. For Madame Defarge, a woman with animosity, it was necessary to revenge. And it was also necessary for all the oppressed and exploited people to revolt. Dickens, from a Humanitarian point of view, understood them. At the same time, he strongly condemned acts of violence of civilians and describe them as unruly mobs. According to Dickens what they had was just crazy excitement and patriotic enthusiasm without the slightest sympathy for human beings. The author made a detailed description of their brutality.

Dickens arranged a tragic and unfortunate ending for this typical representative of the poor masses. Here we saw the author's idea advocated in the novel: tolerance, love, no counter-violence. He used the ending of Madame Defarge to warn people, "no matter who marked counter-violence, and violate the spirit of Christian-kindness was bound to boomerang." This showed that the ideological limitations of Dickens resulting from his class interests and the lives of the era. So he adopted the petty bourgeoisie thinking and ideology to criticize the feudal aristocracy and reflect the French Revolution.

\section{Conclusion}

Dickens believed in Humanitarianism so much that he did many things to help the poor people and call on others to believe Humanitarianism and use it to solve the social problems. In the novel A Tale of Two Cities, he portrayed different types of characters who had various ending to inspire people to be kind and forgiving.

Dickens had an unfortunate childhood and he had to live depending on himself through hard works. He was once despised and laughed at by the rich. That's the reason why he sympathized with the poor people and wrote so many Humanitarian works including $A$ Tale of Two Cities. In the story of $A$ Tale of Two Cities, there are 5 major characters: Doctor Manette, Darnay, Lucy, Carton and Madame Defarge who separately stands for forgiveness, kindness, perfection, self-sacrifice and cruelty.

As the restrictions of history, he could not see a way to resolve the basic contradictions of society. So his works can only publicize the bourgeois Humanitarianism. He tried his best to exaggerate the terror of the French Revolution. He used this to admonish the class who has the dominion of England. He dreamed to solve the contradictions between social classes and complex social problems with compromise. He sympathized with the oppressed working people, and at the same time, he stood against people's violent revolution. He was completely afraid of the revolution which was the limitations of his thought.

In his view, if all the French nobles give up their privilege voluntarily like Darnay, if all the intellectuals could expose corrupt practices like Doctor Manette, and if everybody is willing to do things for friends like Carton, the world would be nicer. Then the revolution would have never happened and all the people would live happily together.

\section{Acknowledgements}

My heart-felt gratitude first goes to Bruce Gao, the Editorial Assistant of Asian Social Science. He has assisted me enormously and guided me along the difficult path towards seeing completion of this thesis.

I would like to express my heartfelt gratitude to my colleagues in Taishan University, Professor Xu Xiaoguang, Professor Zhang Qingyun, Professor Chenxia and other colleagues who have given me constructive suggestions and important instructions.

Lastly, I cannot put an end to my acknowledgements without mentioning my husband and my lovely daughter, who very often surprises me with her special way of care. I love this memory. 


\section{References}

Dickens, C. (1994). A Tale of Two Cities. Beijing: Foreign Language Press.

Du, L. (2008). Realizing the Humanitarianism That Is from Dickens's Novels. Journal of North China Institute of Water Conservancy and Hydroelectric Power.

Gilmour, R. (1986). The Novel in the Victorian Age: A Modern Introduction. New York: Edward Arnold Ltd.

Ian, D. (1992). Modern Romance and Transformations of the Novel the Gothics Scott Dickens. Cambridge: Cambridge University.

Li, X. M. (2002). A Tale for Two Cities. Nei Meng Gu: Nei Meng Gu People’s Press.

Liang, X. D. (2004). An Analysis of the Humanistic Theme of A Tale of Two Cities. Journal of Ningbo University.

Nelson, H. S. (1991). Charles Dickens. Boston: Twayne Publisher.

Page, N. (1984). A Dickens Companion. London: The Macmillan Press LTD.

Woodcock, G. (Ed.). (1994). A Tale of Two Cities. Beijing: Foreign Language Press.

Zhang, B. X., \& Ma, J. J. (1998). A Course Book of English Literature. Wuhan: Wuhan University Press.

Zhang, X. J. (2002). Humanitarianism in A Tale of Two Cities of Dickens. Newspaper of Jinan University (3th ser. 2.4).

Zhang, Y. Q. (2012). The Analysis of Dickens's Humanitarianism in A Tale of Two Cities. English Square (Academic Research).

Zhao, Y. Q. (1996). The Analysis on Dickens's Long Novels. Bei Jing: Social Sciences Academic Press.

\section{Copyrights}

Copyright for this article is retained by the author(s), with first publication rights granted to the journal.

This is an open-access article distributed under the terms and conditions of the Creative Commons Attribution license (http://creativecommons.org/licenses/by/3.0/). 